69. Ивановский Н.И. Причины устойчивости раскола // Н.И. Ивановский. Собр. соч. Т. 1. - Казань: Изд-во Казан. императ. ун-та, 1898.

70. Ковылин И.А. Чин оглашения входящим в православную веру // Сборник для истории старообрядчества / сост. Н.И. Попов. - М.: Изд-во Каткова и Кํ, 1864.

71. Соловьев В.С. Русская идея. - Брюссель: Жизнь с Богом, 1987.

72. Постановления Освященного Собора Русской Православной Церкви (состоявшегося в граде Москве 16-19 октября 2007 г. Н. ст.) / Русская Православная Старообрядческая Церковь: Официальный сайт Московской митрополии. М., 2012 [Электронный ресурс]. - Режим доступа: http://rpsc.ru/documents/postanovleniya-coborov/ postanovleniya-osvyaschennogo-sobora-russkoy-pravoslavnoystaroobryadcheskoy-tserkvi-sostoyavshegosya-v-grade-moskve2007-goda

73. Езеров А.В., Шишкин А.В. Хроника Освященного Собора РПСЦ 2007 года глазами его делегатов / Современное Древлеправославие. М., 1998-2013 [Электронный ресурс]. Режим доступа: http://www.staroobrad.ru/modules.php?na me $=$ News2\&file $=$ article\&sid $=232$

74. Симеон (Дурасов), священноинок. Рассмотрение нового проекта «Чина присоединения к древлеистинной (старообрядческой) Русской Церкви приходящих от никонианской ереси» / Крылья голубиные [б/м, б/г] [Электронный ресурс]. - Режим доступа: http://posad.1gb.ru/default. aspx?ti=1\&hti $=87$

УДК 7.01/04(47+57)

ББК 85.0

\title{
С.В. ИВАНОВА
}

\section{МЕТАМОРФОЗЫ РОССИЙСКОЙ ТРАДИЦИИ ИКОНОГРАФИИ ВОСКРЕСЕНИЯ}

Рассматривается изменение иконописной традиции в иконографии Воскресения в России XVIII века. Исследуется новый тип иконографии, который появляется в это время, и делается вывод о его несомненной связи с гравюрами нидерландских Библий и циклом иллюстраций к Апостольскому символу веры. В связи с этим начинает переосмысляться древний православный образ Воскресения. Ключевые слова: иконография Воскресения, Пасха, иконы Воскресение, Сошествие во ад, Библия Пискатора, «Библия в лицах», Апостольский символ веры, Воскресение «полного извода».

B пасхальной иконографии в России на рубеже XVII века появляются те изменения, которые трудно объяснить как закономерное развитие прежней традиции. Византийская икона Пасхи - «Воскресение»,

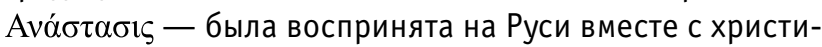
анством. Иконография Воскресения в последующие века свидетельствует о том, что русским иконописцам были известны все новые композиционные типы этого образа, появлявшиеся в Византии. И хотя на Руси создавались и самобытные композиционные решения, их основная идея не отличалась от идеи византийского образа, проникнутого светом и торжеством победы, они в полной мере отражают святоотеческое учение о Воскресении.

Однако в конце XVI - начале XVII веков в России появляется совершенно новая икона, также надписанная «Воскресение», но объединяющая два разных сюжета, с-поразительным соотношением частей. 0браз, который можно было бы отождествить с православной иконой Воскресения, расположен внизу, а над ним оказывается западноевропейское «Восстание от Гроба», до того времени еще неизвестное на Руси. Эта композиция требует внимательного анализа и специального комментария.
Понять происхождение подобного произведения, исходя из логики представленных изображений, невозможно. Можно лишь предположить наличие у иконописца стремления совместить два образа (православный и католический), а также представить Воскресение не только в его абсолютном значении - в традиции православной иконографии, но и в земном плане - как в образе «Восстание от Гроба», широко распространенном в Западной Европе.

Примером такого совмещения может послужить византийская икона XIV века из Македонии: на ней в нижнем регистре изображены жены-мироносицы у гроба (земной план), а в верхнем регистре - сам образ Воскресения (Анастасис). Однако на новой иконе, напротив, земное возвышается над небесным - то есть явно совершается нечто иное.

Что могло повлиять на столь странное решение? Почему тот праздничный образ, который до сих пор почитали отдельно, объединяется с новым, прежде неизвестным в России? Почему образ, который традиционно располагался вверху ${ }^{1}$, вдруг оказывается в нижней части иконы?

\footnotetext{
${ }^{1}$ См., напр., схемы расположения сюжетов в каппадокийских храмax IX-XI веков и фотографии фресок [1]. Напомним расположение
} 
Чтобы ответить на эти вопросы, необходимо найти и проанализировать источник, повлиявший на возникновение этой новой иконографии.

Как уже отмечалось, при осведомленности русских иконописцев в художественных процессах, происходивших в Византии, иконописная традиция Воскресения в восточном христианстве была едина. Но с конца XVII начала XVIII веков в русском искусстве появляются новые образцы, которые привлекают внимание иконописцев. Это протестантские «Библии в лицах», состоящие из гравюр на библейские сюжеты с подписями на латинском языке. Издания XVI-XVII столетий - печатные книги определенного тиража, которые переиздавались неоднократно, поэтому распространение, а следовательно, и влияние их было достаточно велико. При немалой стоимости экземпляры этих Библий покупали и привозили в Россию. Нидерландские и немецкие «Библии в лицах» находились не только в частных собраниях, их в качестве вклада передавали в монастыри. Наиболее известной была Библия Пискатора², названная по имени издателя. Ее экземпляры входили в собрания царской семьи (Алексея Михайловича, Петра I), крупных государственных деятелей и церковных иерархов, среди ее владельцев - бояре, купцы и иконописцы. Вслед за ней по популярности в России называются Библии Мериана и Борхта [4, S. 19-20].

В Библии Пискатора в евангельском цикле Воскресение не представлено. Оно представлено в другом разделе, не только после Евангелия, но и после Деяний апостолов, на гравюре Мартина де Воса, которая относится к циклу Символа веры. Именно это изображение с XVII века начинает активно копироваться в России и в росписях соборов, и в новых иконах. Прежде чем перейти непосредственно к его анализу, необходимо разобраться, что же на нем показано, то есть выяснить, что, собственно, изображается на гравюре, иллюстрирующей Символ веры. Или иначе: какой же Символ она иллюстрирует?

К Символу веры Отцы Церкви относились предельно внимательно - ни одна формула не может быть в нем изменена, ни один догмат не может быть добавлен. Православная Церковь исповедует Символ веры, приня-

фрески Анастасис в конхе монастыря Спасителя «в Полях» («Монастырь Хора», Константинополь); место Анастасис в росписи русских церквей: Мирожского монастыря (около Пскова), церкви Успения на Волотовом поле, Феодора на Ручью (Великий Новгород) [2] и др.

2 Значение Библии Пискатора в России изучено довольно полно, а именно - ее влияние на конкретные произведения и на культуру в целом. Это исследования русских гравюр Д.А. Ровинского, наблюдения Н. Покровского, касающиеся росписей ярославских храмов. И.Л. Бусевой-Давыдовой сделаны культурологические выводы о роли западноевропейских образцов в истории русского искусства. А.В. Гамлицкий исследовал издания нидерландских Библий, сохранившиеся в русских собраниях, и их иконографические источники [3]. 0.А. Белобровой опубликованы вирши, служащие переводом латинских подписей гравюр. Детальное изучение влияния нидерландских гравюр на храмовую роспись (на примере Введенского собора Толгского монастыря) предпринято Е.Л. Шумилиной. Однако остаются некоторые аспекты, требующие отдельного комментария; в первую очередь - иллюстрации Апостольского Символа веры. тый на Первом (325 год, Никея) и Втором (381 год, Константинополь) Вселенских соборах. В Библии Пискатора представлен другой Символ, «апостольский» ${ }^{3}$, состоящий из двенадцати вероисповедальных формул, каждая из которых, по католическому преданию, была по очереди произнесена определенным апостолом, от Петра до Матфея, избранного вместо Иуды (Воскресение названо в пятой формуле, которая приписывается апостолу Фоме). В пятом члене православного Символа веры излагается догмат о Воскресении: «И воскресшаго в третий день по Писанием». Соответствующая ей пятая формула Апостольского Символа веры значительно отличается, так как содержит не один, а два догмата: «Сошел во ад, в третий день воскрес из мертвых».

Первое изображение Сошествия ${ }^{4}$ появляется в каролингской культуре, в составе иллюстрации Апостольского Кредо - это миниатюра манускрипта, известного ныне как Утрехтская псалтирь (начало IX в.), названная по месту своего хранения - городу Утрехт. Затем образ «Сошествие во ад» получает распространение в искусстве центральной и северной Европы, появляясь не только в иллюстрациях Апостольского символа, но и в христологических циклах - росписях храмов, миниатюрах, литье [7]. Это образ, относящийся к страданиям Христа и показывающий драматический момент: Христос с орифламмой [8] идет по направлению к адскому чудовищу, в то время как на Него нападают ужаснейшие демоны.

К концу XV века традиция подобных изображений угасает. Однако неожиданно (если рассматривать собственно историю искусства) на севере Европы в середине XVI столетия интерес к этому сюжету вспыхивает с новой силой. Появляются картина Питера Хёйса «Христос в аду» и гравюра Питера Брейгеля «Христос в преисподней». Внимание к этому сюжету можно объяснить тем, что Апостольское Кредо в очередной раз используется новой конфессией теперь протестантизмом, - стремящейся обособиться от общепринятого в тот момент на Западе католицизма. Поэтому лютеранские печатные Библии с гравюрами включают в свой состав именно этот Символ веры.

\footnotetext{
${ }^{3}$ В европейской науке он датируется не ранее VI-VIII веков $[4$, S. 379; 5].

${ }^{4}$ В искусстве Западной Европы его появление обусловлено иным осознанием самого феномена образа, нежели в искусстве восточного христианства. В византийской и каролингской культурах образ трактуется не одинаково. В то время как защитники икон в восточной части империи утверждают ценность молельной почитаемой иконы (иконы проскинес), «Каролинговы книги» относят изображение в значительной мере к ряду зрительного изложения («Библии для неграмотных») или мнемонического пособия. Образ в последнем случае - напоминание, толчок для благочестивого размышления. Отсюда понятно, почему в православии изначально нет иконы Сошествия во ад, хотя само событие никогда не отвергалось. Молельный образ Сошествия чужд православию, так как оно совершилось в период между крестной смертью Христа и Его Воскресением, то есть в то время, когда Он был мертв. Богословие православной иконы исключает возможность возникновения такого изображения. И хотя в православной церкви множество богослужебных чтений и песнопений говорят о Сошествии, оно не изображается: показать отдельно «душу Христа», «пока тело находилось в гробнице» [6, р. 227], на иконе проскинес невозможно.
} 
В Реймском миссале, созданном в королевском скриптории (1285-1297), пятая формула о Сошествии и Воскресении разделяется на два книжных разворота (Сошествие завершает страстной цикл, а на следующем развороте репрезентировано все, связанное с Воскресением). В новых же протестантских Библиях два догмата, произнесенные апостолом Фомой, объединяются не только на одной странице, но и в одной гравюре. Мартин де Вос показал здесь сразу оба названных события в их последовательности: на первом плане - Сошествие во ад, на втором - Воскресение. Можно предположить, что образцом части, представляющей Сошествие, могла послужить гравюра Дюрера из его цикла «Малые страсти». Причем гравюра Дюрера копируется без учета того, что изображение на оттиске будет перевернуто - поэтому в Библии Пискатора, в нарушение сложившегося канона, появляется Сошествие, в котором ад находится не слева, а справа от Христа. Образ «Восстание от гроба», расположенный выше и выделенный более светлым тоном, иллюстрирует вторую часть догмата: фигура Христа воспаряет над могильным отверстием, видны поверженные (или спящие) стражники.

Внизу на латыни напечатана формула из Апостольского Кредо. В некоторых экземплярах в России под нею есть рукописная вставка - перевод. Латинская строчка, дословно означающая «Сошел во ад. В третий день воскрес», передана виршами ${ }^{5}$ :

\section{Низшедша во ад пленных свободити \\ И диаволю крепость разрушити. \\ Из мертвых же в день третий воскресшаго \\ И весь род адамль от уз изведшаго.}

Первые две строки переводят слова «Сошел во ад» и относятся к нижней части гравюры; две следующие догмат «Воскрес в третий день» - должны пояснять вторую, верхнюю часть. Несмотря на наличие перевода, анализ изображений, созданных под влиянием этой гравюры, показывает, что русскими художниками она воспринималась как единое целое - а именно как одна, неделимая на сюжеты картина, связанная с определенной формулой Символа веры. Правда, не было осознано, что в данном случае формула эта принадлежит неправославной традиции. В порядке расположения в Символах эти формулы совпадают - гравюра соответствует также пятому члену в православном исповедании. И буквенное обозначение «5»(Е), данное рядом с виршами, возможно, оказалось гарантом благонадежности, связывая новый визуальный ряд с известным содержанием. В результате две разные иллюстрации прочитывались как один развернутый образ. Сами слова о сошествии в принципе не противоречат вести о Воскресении, которая принимается как основная.

Гравюра «Сошествие во ад - Восстание от Гроба» из Апостольского Кредо начинает копироваться в составе новой для русского искусства иконы «Символ веры». Мы

\footnotetext{
${ }^{5}$ В публикацию 0.А. Белобровой виршей Мардария Хоныкова перевод
} Апостольского Символа веры не вошел. видим ее, например, в клейме, которое должно означать «Воскресение», на соловецкой иконе из собрания музея «Коломенское» - целиком вся двухчастная композиция надписана «И воскресшаго в третий день» ${ }^{6}$ (как видим, сошествие не упоминается: при копировании визуального ряда Символ веры остается неизменным). Похожая композиция дана и на иконе из московского храма св. Григория Чудотворца (1668-1669, ГРМ). В обоих случаях по отношению к гравюре соотношение частей здесь лишь слегка изменено: «Восстание от Гроба» вынесено на передний план и дано крупнее. Изменены и отдельные детали: нагота людей прикрыта, Адам и Ева - еще в пещере. Но последовательность событий дана так же, как и в Апостольском Кредо, сохранены облачка вокруг Христа, даже копье стражника все так же нацелено вверх. То, что соотносится в этом изображении со знакомой традицией и поэтому узнается, принимается иконописцем и копируется. Те же элементы, которые не вписываются в привычную схему, «игнорируются» и не переносятся на новую икону.

Так, остались «незамеченными», например, пологий спуск под ногами Христа (вместо пропасти), уже спасенные из ада и отдельно стоящие обнаженные мужчина и женщина (Адам и Ева, причем Адам в очередной раз с яблоком в руке), наконец, отвратительные бесы, возвышающиеся над головой Христа, которые корчатся и целятся в Него и людей - обычные персонажи «Сошествия».

В качестве образа «Воскресение» эта гравюра воспроизводится и в монументальных росписях. Такова же композиция в росписи артели Гурия Никитина СпасоПреображенского собора Свято-Евфимиева монастыря в Суздале (1689). В Введенском соборе Толгского монастыря (Ярославская обл., 1690-е гг.) она представлена дважды - на западном своде центрального нефа, обе части рядом [10, с. 68-69], как и в росписи Гурия Никитина, и на откосе окна - только нижняя ее часть (Сошествие), где полуобнаженные фигуры Адама и Евы заменяются фигурами Иоанна Предтечи и Моисея, облаченными в античные одежды (но сохранены ракурсы: Моисей дан в трехчетвертном развороте, как Адам на гравюре, рука так же приподнята). Место образа «Восстание от Гроба» с гравюры де Воса здесь занимают деревья, обозначающие райㄱ.

Подобные модификации образов гравюры можно наблюдать и на иконах. Три обнаженные фигуры, протягивающие к Христу руки и еще только собирающиеся выйти из ада, соотносятся на иконах также с тремя фигурами: иногда это Адам и две женщины перед ним; иногда — три женщины, одетые в одежды разного цвета. Дальнейшее развитие иконографии идет по линии усложнения и добавления сюжетов: ловля рыбы на Генисаретском озере, жены-мироносицы у гроба, шествие праведных в рай, история благоразумного разбойника и проч. Все они, наполняя пространство вокруг «Сошествия во ад - Вос-

\footnotetext{
${ }^{6}$ См. репродукции к статье [9].

${ }^{7}$ См.: [10, с. 185$]$.
} 
стания от Гроба», с одной стороны, способствуют окончательной адаптации этой композиции, с другой - еще более затемняют основной смысл изображенного.

Очевидно, то обстоятельство, что Воскресение в Библии Пискатора оказалось не проиллюстрировано в Евангельском цикле, заставило мастеров-иконописцев обратиться к циклу Апостольского Символа веры, где Воскресение (как «Восстание от гроба») представлено. Именно под влиянием гравюр «Сошествие во ад - Восстание от гроба», иллюстрирующих формулу Апостольского Символа веры, и возникает новая икона в русском искусстве. Расположение сюжетов здесь повторяет авторское решение, использованное в иллюстрации, которое продиктовано принципом соответствия каждой отдельной гравюры одной формуле (даже если формула включает в себя не один, а два догмата). Вверху - западноевропейское «Восстание от Гроба», внизу - изображение, иногда почти повторяющее традиционное «Воскресение» (Анастасис), иногда копирующее черты «Сошествия во ад». Появление подобных икон совпадает с наблюдением относительно того, в каких областях были известны «Библии в лицах» [3]. В устном обиходе приживается и название «Сошествие во ад» - при этом важно, что оно никогда не попадало на саму икону, которая всегда надписывалась как «Воскресение».

Так в результате механического копирования образ, связанный с другой культурой и другой конфессией, был адаптирован и стал восприниматься как икона Воскресения. Иконографические черты гравюры «Сошествие во ад - Восстание от Гроба» были слегка видоизменены в соответствии с привычной традицией, и смысловой комментарий оказался утрачен - а именно, что это совмещение двух изображений, связанных с Кредо, не принятом в православии. Эта гравюра - то недостающее звено, которое объясняет, почему так кардинально меняется традиция пасхальной иконографии в России. Она также дает возможность объяснить использование названия
«Сошествие во ад» применительно к православной иконе Воскресения. При этом сама иконография Воскресения в православии изначально совершенно чужда тем процессам, которые начались под воздействием иллюстрированных Библий. Возникает та смысловая трансформация, которая повлияла на дальнейшее восприятие этой иконы.

\section{Список литературы}

1. Restle M. Die Byzantinische Wandmalerei in Kleinasien. B-de 1-3. - Recklinghausen, 1967.

2. Царевская Т.Ю. Роспись церкви Феодора Стратилата на Ручью и ее место в искусстве Византии и Руси второй половины XIV века. - М.: Северный паломник, 2007.

3. Гамлицкий A.B. Западноевропейские лицевые Библии в России XVII-XVIII веков. Владельцы и формы бытования // Филевские чтения. Тезисы конференции. - М., 1999.

4. Loerke M.-M.-0. Hollenfahrt Christi und Anastasis. Ein Bildmotiv im Abendland und im christlichen 0sten. Inaugural-Dissertation zur Erlangung der Doktorwürde der Philosophischen. Fakultät I (Philosophie, Sport, Kunstwissenschaften) der Universität Regensburg. Regensburg, 2003.

5. Kelly J. Altchristliche Glaubensbekenntnisse. - Göttingen, 1972.

6. Kartsonis A.D. Anastasis: The Making of an Image. Princeton, New Jersey, 1986.

7. Иванова С.В. «Сошествие во ад» или «Воскресение»? // История и культура: Исследования. Статьи. Публикации. Вып. 8 (8). - СПб.: Издательство С.-Петербургского университета, 2010.

8. Иванова С.В. Флаг как воодушевляющий символ (к семантике образа Христа с флагом) // Временник Зубовского института. Вып. 6: Грозное время. Война в зеркале человеческого восприятия. - СПб.: Российский институт истории искусств, 2011.

9. Полякова О.А. Иконография Иисуса Христа. Статья третья // Мир музея. - 2000. - 1(173) январь-февраль.

10. Шумилина Е.Л. Свято-Введенский Толгский монастырь. M., 2010. 